\title{
Outlook of Agricultural Sector in the Face of Changing Global Climate: The Case of Nigeria
}

\author{
Ayodele TR*, Ogunjuyigbe ASO and Ekoh EE \\ Department of Electrical and Electronic Engineering, University of Ibadan, Nigeria
}

Submission: March 05, 2017; Published: March 30, 2017

"Corresponding author: Ayodele TR, Department of Electrical and Electronic Engineering, University of Ibadan, Nigeria, Tel: +2348064339270;

Email: tayodele2001@yahoo.com

\begin{abstract}
The dependence of Nigeria's agricultural sector on climate, in the face of changing global climatic pattern, poses a clear danger to her economic aspiration. This paper therefore discusses the vulnerability of agricultural sector to the problem of climate change in Nigeria. The possible adaptation and mitigation strategies that could surmount the negative impact of climate change is also highlighted. Some of the findings reveal that the Coastal areas and Nigeria's northern food belt are the most vulnerable. Observation from the study shows that the Nigerian government has taken some decisive steps by constituting several agencies and portfolios to tackle issues regarding climate change to safeguard the futures of the country.
\end{abstract}

\section{Introduction}

Nigeria, the largest black African nation, is home to one-in-four African and undoubtedly the most important economic powerhouse on the African continent. In 2014, Nigeria surpassed South Africa to become the largest economy in sub-Sahara Africa, her current GDP totals $\$ 481.07$ billion USD [1]. This figure is expected to see a continued upward trend in the next couple of years as seen from projections. Although Nigeria is currently facing serious economic strain owing to the prolonged drop in global crude oil prices, experts strongly believe there will be a rebound in the country's economy.

This confidence level in the Nigerian economy by most stakeholders is largely due to the steer from the government to diversify the nation's economy to non-oil sectors such as agriculture, solid minerals and manufacturing. Although these sectors seem to be the pillars of modern economies, stakeholders believe the agricultural sector has the singular impact on driving this industrialization effort. To this end, the Nigerian government has placed considerable premium on this sector, investing huge finances to achieve this feat.

With these facilities to boost her agricultural sector in place, Nigeria is on course to achieve her economic goals and continue her dominance of the African economic scene. But higher daily temperatures, reduction in rainy days, flooding of coastal belts and pollution of freshwater habitat: which are the resulting effect of changing global climatic pattern, have a direct correlation with reduced agricultural yield [2] and would considerably impact
Nigeria's economic fortune and make this dream a mere mirage if nothing is done to arrest the situation.

Although climate change is not peculiar to Nigeria, the fact that majority of her workforces live and work in the flood prone low-lying coastline, and the dependence of her population on rain fed agriculture makes Nigeria susceptible. Managing the changing climate as articulated in the literature requires a dual approach; these are mitigation and adaptation strategies. Environmentalists argue that the integration of both strategies (i.e. adaptation and mitigation) to a government action plan on climate change is the keys to successfully addressing current and projected impacts of climate change.

In Nigeria today the discourse on climate change enjoys wide authorship, popular works on climate change from the Nigerian perspective include that done by [3-6], focusing on the proofs of climate change in Nigeria. And those focusing on other aspects like the impact of climate change in Nigeria $[7,8]$ and the possible mitigation strategies [9-11] to curtail the impact on the Nigerian society.

The resulting effect of this knowledge pool has led the government and several interest groups to establish various agencies, task forces and working committees to enact laws to tackle the effect of climate change and foster environmental sustainability. In fact, the Nigerian government's awareness of Nigeria's vulnerability to climate change is evident by various efforts she has 
made to put institutional arrangements in place, like; her accent to the Kyoto-Protocol and the United Nations Framework on climate change, her commitment to the Nairobi Declaration adopted by the African Ministerial Conference on the Environment (AMCAN), the Convention of African Heads of State on Climate Change (CAHOSCC) and her membership of other international, regional protocols and committees. But as recounted by [12-14], despite the dedicated policies and institutions; like the Special Climate Change Unit (SCCU) in the Federal Ministry of Environment, the National Emergency Management Agency (NEMA), the Nigerian Meteorological Agency (NIMET) etc., matching the efforts against results there is a growing public outcry that the steps taken so far dwarfs the current extent to which climate change impacts the average Nigerian.

As, this dilemma ensues, more initiatives and policies with the aim to address the impact of climate change in Nigeria is been developed and implemented. It is, therefore, obvious that going forward there is a need to review the current strategies that have been implemented over time to ascertain their effectiveness with the aim of learning best practices that have yielded good results. This work, therefore, seeks to contribute in this line by presenting holistic evaluation of the current adaptation and mitigation strategies on climate change in the Nigerian Agricultural sector taken into account the part of all stakeholders.

\section{Nigerian agriculture and climate change}

The two distinct seasons' the wet (rainy) season which usually lasts from April to October; and the dry (harrmattan) season which lasts from November till March that characterizes the Nigerian climate is currently being modified. According to reports from the Nigerian meteorological agency, measurements of temperature and rainfall taken in the last 105 years indicate that mean temperatures have risen by an average of $1.20 \mathrm{C}$ and $20 \mathrm{C}$ in the coastal part and the northern part of the country respectively, while the depth of rainfall has also seen a major shift; major cities across the Nigerian coast experienced increased rainfall while other areas experienced a sharp reduction. Other recorded observable weather phenomena indicating the changing Nigerian climate include frequent and severe thunderstorms, lightning, landslides, floods, droughts, bush fires, unpredictable rainfall patterns, sea level rise, increase desertification and land degradation, drying up of rivers and lakes and constant loss of forest cover and biodiversity [4].

The implication of these changes is now being felt in the agricultural sector. On crop and livestock production; severe flooding in coastal settlement has resulted in ruin of crops, massive gully erosion which has washed away the topsoil resulting in land degradation and lowering of soil fertility. While the coastal regions and other flood-prone areas reel from the effect of flooding, the north deals with severe water shortage; drop in annual rainfall and the spate of drought has resulted in reduced irrigation and desertification of arable land in the northern states (Nigerian food belt). It is believed that the effects has reduced crop yield by about 20\%. Fishing activities has also been negatively impacted [15]; rising sea levels resulting in the contamination of freshwater habitat has affected major fishing communities also the drying up of rivers and lakesh as resulted in significant reduction of fish productivity.

Despite the devastating effects of this current changes to the environment, climate scientists argue that the stated occurrences are mere early warning signs of the full scale impact of global warming in Nigeria. It is a general consensus that if global warming persists, average temperatures could increase by $2.5^{\circ} \mathrm{C}$ to $4.5^{\circ} \mathrm{C}$ in next 100 years and the envisaged impact could be devastating [16].

\section{Adaptation strategies}

Agriculture is practiced in all regions in Nigeria and employs the bulk of her labor. The numerous climatic and environmental conditions in Nigeria make it necessary for the country to develop an array of adaptation options that will meet the different conditions of the different ecological locations of the nation. Adaptation strategies in agriculture employed in Nigeria have been categorized by Ifeanyi et al. [17] in to two groups, they are; planned adaptation and autonomous adaptation. Autonomous adaptation refers to reaction of farmers to changing climate patterns, in that he/she changes crops, uses different harvest and planting/sowing dates while planned adaptation measures are conscious policy options or response strategies, often multi-sectoral in nature and aimed at altering the adaptive capacity of the agricultural system of facilitating specific adaptations.

Currently the autonomous adaptation strategy is widely practiced. Although the method has proven effective in part, low knowledge of farmers on climate change and the inaccessibility climate data has largely hampered its success on a grandiose scale [18]. Hence there is the need for a push to a more coordinated style of adaptation. According to Dimelu et al. [19] extension activities will play a crucial role in dealing with the knowledge gap. But as Dimelu et al. [19] pointed out adequate funding, good policy and institutional framework must be put in place before extension activities will be effective.

In the light of the New Agriculture Promotion Policy document in 2016 planned adaptation is projected to be more effective in the coming years. This document is aimed at providing a disciplined approach to the business of Agriculture in Nigeria. The policy document introduces new adaptation concept like encouraging climate smart agriculture, combating erosion, effective water management etc. [20], But the dependence of climate change activities within the Agricultural Promotion Policy document on the Nigeria Agriculture Resilience Framework (NARF) has not been implemented might serve as a challenge going forward. The NARF is developed in setting out approaches that would enhance productivity and boost food security while protecting and strengthening the environment [21-24].

\section{Mitigation strategies}

Mitigation to climate change will involve cutting climate change inducing factors within the Nigerian society and development of policies to discourage fugitive emissions and emissions due to land use which accounts for the bulk of Nigeria's emissions. 
Implementing strategies to cut greenhouse gas emissions world over have its pros and cons. Policies adopted globally might result in the non-exploitation of Nigeria's huge reserves of coal, oil and gas which has a lot of implication on the Nigerian economy.

Since land use is the primary source of emissions in Nigeria, it represents one of the key areas for mitigation work in the Nigeria, which includes best practices to enhance carbon sequestration and reduced emissions; Nigeria has made some strides many of them indirectly. Case in point is the proposed cattle grazing bill that seeks to control manage and control grazing routes and reserves in all parts of Nigeria.

Another area with huge potential for mitigation is in her forest reserves, since forest reserves are the largest sink of greenhouse gas emissions from the atmosphere; Nigeria's vegetation supports the mangrove and rain forests. In the recent years development initiatives have seen the gradual decline of the forests. Policies' discouraging illegal lumbering and provision of marketbased mechanisms to reward or provide incentives for forest conservation or the avoidance of deforestation and sustainable forest management practices has been highlighted by UNEP as a means for mitigating climate change. However, more work needs to be done by the Ministry of Forest resources to preserve our forests and swamps by providing a comprehensive policy document to our grasslands and forests survival.

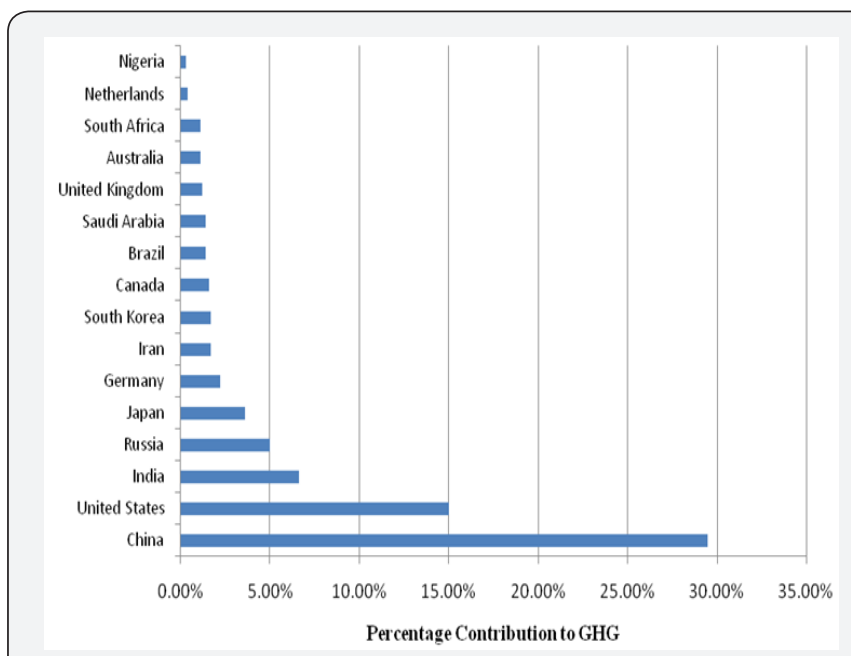

Figure 1: Percentage Contribution of Different Countries to GHG Emission.

Since Nigeria currently contributes a meager fraction of $0.3 \%$ to the world's total GHG emissions, see the contribution of selected countries as shown in the Figure 1 below. Nigeria government can access huge finances to actualize some of her green policies and initiative by ensuring Africa's call for binding ambitious targets for developed countries to secure the price of carbon is materialized. The key areas her voice would play important roles is partnering with other African countries to reform the rules of market mechanisms such as the Clean Development Mechanism to increase accessibility by African countries, the full implementation of the
Nairobi Framework and building capacity in Africa to gain access to the available financial mechanisms (the Clean Development Mechanism, Global Environment Facility, the World Bank and the African Development Bank, among others).

\section{Conclusion}

This study has probed vulnerability of Nigeria's agricultural sector to climate change and has explored her current adaptation and mitigation strategies to the changing climate. It is obvious that changing climate has a negative impact on the Nigerian agricultural sector. Coastal areas and Nigeria's northern food belt are the most vulnerable. Observation from the study shows that the Nigerian government has taken steps to safeguard the futures of her people and the economic fortunes of the country by constituting several agencies and portfolios to tackle issues with climate change. However, the implementation of these initiatives hangs in a balance due to bureaucracy in the legislature to pass some of this framework and policies into law.

\section{References}

1. The World Bank Group (2016).

2. FAO (2012) Climate Change Adaptation And Mitigation Challenges And Opportunities In The Food Sector. Food and Agriculture Organization of the United Nations (FAO) Natural Resources Management and Environment Department.

3. Olaniran O (1991) Evidence Of Climatic Change IN Nigeria Based on Annnual Series of Rainfall of Different Daily Amounts 1919-1985. Climatic Change 19(3): 319-341.

4. Odjugo PA (2011) Climate Change and Global Warming: The Nigerian Perspective. Journal of Sustainable Development and Environmental Protection 1(1): 6-17.

5. Ojekunle Z, Oyebamj FF, Olatunde AK, Amujo TB, Ojekunle OV, et al. (2014) Global Climatic Change in Nigeria: A Reality or Mirage. Global Journal of Human-Social Science: B Geography, Geo-Sciences, Environmental Disaster Management 14 (6): 1-7.

6. Odiana S, Abdulquadir I (2015) An Assessment of the evidence of Climate change in Bauchi, Nigeria. Journal of Applied Science and Environment Management 19(3): 375-381.

7. Odiana S, Abdulquadir I (2015) An Assessment of the evidence of Climate change in Bauchi, Nigeria. Journal of Applied Science and Environment Management 19(3): 375-381.

8. Omoruyi EP, Kunle OA (2008) Effects of Climate Change on Health Risks In Nigeria. Asian Journal of Business and Management Sciences 1(1): 204-215.

9. Ede AN, Oshiga K (2014) Mitigation Strategies for the Effects of Climate Change on Road Infrastructure in Lagos State. European Scientific Journal 10(11): 194-208.

10. Adesina FA, Siyanbola WO, Oketola FA, Pelemo DA, Momodu SA, et al. (1999) Potential of Agroforestry Techniques in Mitigating CO2 Emission in Nigeria: Some Preliminary Estimates. Global Ecology and Biogeography 8(2): 163-173.

11. Chukwuma OM (2014) Review of Studies on Global Warming and Climate Change In Nigeria. International organization of Scientific Research 4(10): 19-27.

12. Ekpoh IJ (2014) Slow Response to Climate Change in Nigeria: Need for Urgent and Comprehensive Action. Studies in Social Sciences and Humanities 1(1): 19-29. 
13. Onwubiko E (2015) Nigeria's Tepid Response to Climate Change.

14. Chilaka Q Nwabeze G, Odili O (2014) Challenges of Inland Artisanal Fish Production in Nigeria: Economic Perspective. Journal of Fisheries and Aquatic Science 1-5.

15. Ayodele TR, Olanrewaju OA (2012) Energy and Climate Change: Critical Reflection on the African Continent. Journal of Sustainable Development in Africa 14(6): 84-97.

16. Kinnagbe O, Irhoibe IJ (2014) Agricultural Adaptation Strategies to climate change Impacts in Africa: A Review. Bangladesh Journal of Agricultural Resources 39(3): 407-418.

17. Ifeanyi-obi C, Etuk U, Jike-wai O (2012) Climate Change, Effects and Adaptation Strategies; Implication for Agricultural Extension System in Nigeria. Greener Journal of Agricultural Sciences 2(2): 53-60.

18. Dimelu M, Edoka M, Emodi A (2014) Challenges in Building Climate Change Mitigation and Adaptation Capacity ofw. Production Agriculture and Technology Journal 10(1): 110-122.
19. FARMD (2016) The Agriculture Promotion Policy (2016-2020). Federal Ministry of Agriculture and Rural Development, Abuja, Nigeria.

20.Amobi D, Onyishi T (2015) Governance And Climate Change In Nigeria:A Public Policy Perspective. Journal of Policy and Development Studies 9(2): 199-210.

21. Harvey F (2007) UN climate panel detailed potential for global conflict.

22. Nyong A, Adesina F, Elasha BO (2007) The value of indigenous knowledge in climate change mitigation and adaptation strategies in the African Sahel. Mitigation and Adaptation Strategies to Global Climate Change 12: 787-797.

23. Thomson Reuters (2011) Floods kill 98 in southwest Nigeria-Red Cross.

24. Wyett K (2014) Escaping a Rising Tide: Sea Level Rise and Migration in Kiribati. Asia \& the Pacific Policy Studies 1(1): 171-185.

\section{Your next submission with Juniper Publishers will reach you the below assets}

- Quality Editorial service

- Swift Peer Review

- Reprints availability

- E-prints Service

- Manuscript Podcast for convenient understanding

- Global attainment for your research

- Manuscript accessibility in different formats

( Pdf, E-pub, Full Text, Audio)

- Unceasing customer service

Track the below URL for one-step submission https://juniperpublishers.com/online-submission.php 